\title{
The Effectiveness of Entomopathogenic Nematode Steinernema spp. on Mortality of Lepidiota stigma F. (Coleoptera: Scarabaeidae)
}

\author{
Toto Sunarto $^{1 *}$, Aep Wawan Irwan ${ }^{2}$ \\ ${ }^{1)}$ Department of Plant Pests and Diseases, Faculty of Agriculture, Padjadjaran University, Jatinangor, West Java, Indonesia, \\ 45363 \\ ${ }^{2)}$ Department of Agronomy, Faculty of Agriculture, Padjadjaran University, Jatinangor, West Java, Indonesia, 45363 \\ *Corresponding Author: toto.sunarto@unpad.ac.id
}

Received October 16, 2019; revised October 17, 2019; accepted December 17, 2019

\begin{abstract}
Integrated Pest Management (IPM) is an alternative way to reduce use of synthetic pesticides. One of them is using the natural enemy of insect pests, such as predatory insects, parasitoid, and entomopathogenic nematodes. So far the control of Lepidiota stigma $\mathrm{F}$. in sweet potatoes carried out with synthetic insecticides that has negative impact to the environment. Another alternative of L. stigma control with entomopathogenic nematodes (Steinernema spp.). This study aimed to obtain Steinernema spp. concentration that effective against mortality of L. stigma larvae. This experiment was conducted at Plant Nematology Laboratory, Faculty of Agriculture, Universitas Padjadjaran from Februari - August 2019. The research used was experiment method with Completely Randomized Design consisted of six treatments and five replications. The treatment were Steinernema spp. concentration of 0,50, 100, 150, $200 \mathrm{IJ} \mathrm{ml}^{-1}$ of water, and Karbofuran dose of $15 \mathrm{~kg} \mathrm{ha}^{-1}$ $\left(0.002 \mathrm{~g} / 12.56 \mathrm{~cm}^{2}\right)$. The results showed that Sterinernema spp. has an effect on mortality of Lepidiota stigma larvae at 24 HAA (Hours After Application) and 48 HAA. Steinernema spp. at concentration of $150 \mathrm{IJ} \mathrm{ml}^{-1}$ capable effectively causing the mortality of Lepidiota stigma larvae of $68 \%$ at 48 HAA.
\end{abstract}

Key words : Lepidiota stigma F., Steinernema spp., sweet potato

\author{
ABSTRAK \\ Keefektivan Nematoda Entomopatogen Steinernema spp. \\ Terhadap Mortalitas Lepidiota stigma F. (Coleoptera:Scarabaeidae)
}

Pengendalian Hama Terpadu (PHT) merupakan cara alternatif untuk mengurangi penggunaan pestisida sintetis. Salah satunya dengan memanfaatkan musuh alami serangga hama, seperti serangga predator, parasitoid, dan nematoda entomopatogen. Selama ini pengendalian Lepidiota stigma F. (uret pada tanaman ubi jalar) dilakukan dengan insektisida sintetis yang berdampak negatif bagi lingkungan. Alternatif lain untuk pengendalian L. stigma dengan nematoda entomopatogen (Steinernema spp.). Tujuan penelitian ini untuk mendapatkan konsentrasi Steinernema spp. yang efektif terhadap mortalitas larva L. stigma. Percobaan ini dilaksanakan di Laboratorium Nematologi, Departemen Hama dan Penyakit Tumbuhan, Fakulas Pertanian Universitas Padjadjaran, bulan Februari- Agustus 2019. Penelitian menggunakan metode percobaan dengan Rancangan Acak Lengkap yang terdiri dari 6 perlakuan dan 5 ulangan. Perlakuan terdiri dari: konsentrasi Steinernema spp. 0, 50, 100, 150, $200 \mathrm{JI} / \mathrm{ml}$ air dan Karbofuran dosis $15 \mathrm{~kg} / \mathrm{Ha}\left(0,002 \mathrm{~g} / 12,56 \mathrm{~cm}^{2}\right)$. Hasil penelitian menunjukkan bahwa Sterinernema spp. berpengaruh efektif terhadap mortalitas larva Lepidiota stigma pada pengamatan 24 JSA (jam setelah aplikasi) dan 48 JSA. Steinernema spp. pada konsentrasi $150 \mathrm{JI} / \mathrm{ml}$ efektif menyebabkan mortalitas larva Lepidiota stigma $68 \%$ pada 48 JSA..

Kata kunci : Lepidiota stigma F., Steinernema spp., ubi jalar

\section{PENDAHULUAN}

Salah satu hama yang menyerang tanaman ubi jalar adalah uret atau larva Lepidiota stigma (Coleoptera: Scarabaeidae). L. stigma menyerang akar dan bagian ubi jalar sehingga mengakibatkan penurunan hasil panen ubi jalar. Uret instar 3 dapat memakan kulit akar sampai habis. Adanya kerusakan akar dapat menyebabkan terjadinya kelayuan pada tanaman muda dan sering menimbulkan kematian (Saragih, 2009). Larva Lepidiota juga menyerang akar tanaman kacang-kacangan di dunia (Pathania, 2014).
Pengendalian L. stigma saat ini masih menggunakan insektisida kimia. Akan tetapi, dengan adanya kekhawatiran tentang keamanan dan pencemaran lingkungan, maka perlu pendekatan untuk mengembangkan PHT (pengendalian hama terpadu) untuk hama ini. Salah satu komponen PHT adalah pengendalian secara biologi yaitu menggunakan entomopatogen alami.

Entomopatogen alami (nematoda, jamur, bakteri dan virus) adalah komponen penting dalam ekosistem tanah yang dapat mengendalikan hama di tanah secara efektif. Pengendalian Lepidiota dengan jamur, 
nematoda dan bakteri memiliki prospek di masa depan dalam pengendalian Lepidiota (Chandel et al., 2015).

Nematoda entomopatogen (NEP) telah berhasil diaplikasikan terhadap serangga yang hidup di tanah (aplikasi tanah) serta serangga di atas tanah (semprotan daun) (Arthers et al., 2004). Pemanfaatan NEP berkembang pesat di Jepang, Turki, Thailand, dan di negara-negara Eropa, tetapi lebih banyak digunakan dalam pengendalian hama uret pada komoditas hortikultura, pertanian, dan kehutanan (Maneesakorn et al., 2010). Keunggulan NEP adalah mudah diperbanyak secara massal baik in vivo maupun in vitro (Upadhyay et al., 2015). NEP yang diketahui paling efektif terhadap hama uret tebu adalah Steinernema sp. dan Heterorhabditis sp. yang berturut-turut dari famili Steinernematidae dan Heterorhabditidae (Abdolmaleki et al., 2016).

NEP mampu menyebabkan mortalitas pada inangnya dalam waktu 24-48 jam karena dibantu oleh bakteri simbion masing-masing, yaitu bakteri Xenorhabdus sp. pada Steinernema sp. dan Photorhabdus sp. pada Heterorhabditis sp. (Dubey et al., 2013).

Steinernema sp. dan Heterorhabditis sp. merupakan NEP yang hidup dan menginfeksi serangga hama yang habitatnya di dalam tanah. Larva nematoda ini yang paling aktif menginfeksi inang serangga adalah instar 3 yang juga disebut juvenil infektif. Untuk menemukan lokasi inang (host foraging), kedua spesies NPS menggunakan strategi menyergap (ambush) atau memburu (cruise) (Andaló et al., 2017). Jenis tanah yang mengandung pasir lebih ideal untuk perkembangbiakan NEP karena mempermudah pergerakan nematoda dalam upaya menemukan serangga (Kapranas et al. 2018). Suhu dan kelembaban di dalam tanah juga mempengaruhi keberhasilan NEP dalam menemukan inangnya (Lee et al. 2016), karena pada suhu rendah $\left(<25^{\circ} \mathrm{C}\right)$ menyebabkan NEP inaktif, sehingga mengurangi keefektifannya mengendalikan inang.

Kecepatan membunuh NEP terhadap inang merupakan refleksi dari daya bunuh bakteri simbion yang dibawa masing-masing spesies NEP di dalam intestinumnya, terutama jumlah bakteri simbion yang dilepas ke dalam hemolimfa inang untuk membunuhnya secara efektif (Sicard et al. 2006).

Pengendalian L. stigma pada tanaman ubi jalar dengan nematoda entomopatogen (Steinernema spp.) belum banyak dilakukan. Oleh karena itu perlu dilakukan penelitian tentang efektifitas nematoda entomopatogen (Steinernema spp.) terhadap mortalitas larva Lepidiota stigma. Penelitian ini dilkukan untuk mendapatkan konsentrasi Steinernema spp. yang efektif terhadap mortalitas larva Lepidiota stigma pada tanaman ubi jalar.

\section{BAHAN DAN METODE}

Percobaan dilaksanakan di Laboratorium Fitopatologi, Divisi Nematologi Tumbuhan, Departemen Hama dan Penyakit Tumbuhan, Fakultas
Pertanian, Universitas Padjadjaran, Jatinangor, mulai bulan Februari sampai Agustus 2019. Alat yang digunakan adalah mikroskop binokuler, mikroskop monokuler, kuas kecil, petri dish, pinset, mikro pipet, toples, ember, gelas, kertas saring, pisau. Bahan yang digunakan adalah Furadan Prima-Fur 3GR (karbofuran), larva Lepidiota stigma instar 3, nematoda entomopatogen (Steinernema spp.), ubi jalar dan akuades.

\section{Rancangan Penelitian}

Penelitian menggunakan metode percobaan dengan Rancangan Acak Lengkap (RAL), yang terdiri dari 6 perlakuan dan 5 ulangan. Perlakuan sebagai berikut:

A. Konsentrasi Steinernema spp. 0 JI / ml air (Kontrol )

B. Konsentrasi Steinernema spp. $50 \mathrm{JI} / \mathrm{ml}$ air

C. Konsentrasi Steinernema spp. $100 \mathrm{JI} / \mathrm{ml}$ air

D. Konsentrasi Steinernema spp. $150 \mathrm{JI} / \mathrm{ml}$ air

E. Konsentrasi Steinernema spp. $200 \mathrm{JI} / \mathrm{ml}$ air

F. Karbofuran dosis $15 \mathrm{~kg} / \mathrm{Ha}(0,002 \mathrm{~g} / 12,56$ $\mathrm{cm}^{2}$ )

\section{Perbanyakan Nematoda Entomopatogen \\ (Steinernema spp.)}

Steinernema spp. diperoleh dari koleksi Divisi Nematologi Tumbuhan, Laboratorium Fitopatologi, Departemen Hama dan Penyakit Tumbuhan, Fakultas Pertanian Universitas Padjadjaran. Steinernema spp. yang digunakan adalah Steinernema isolat Lembang yang diperbanyak pada larva Tenebrio molitor dengan metode White trap. Untuk mendapatkan jumlah nematoda yang sesuai dengan perlakuan dilakukan perhitungan setiap $10 \mu \mathrm{l}$ suspensi nematoda yang telah dipanen dengan menggunakan mikroskop monokuler, kemudian dilakukan standarisasi jumlah nematoda.

\section{Koleksi Larva Lepidiota stigma}

Larva Lepidiota stigma instar 3 dikoleksi dari pertanaman ubi jalar di Tanjungsari, Kabupaten Sumedang. Larva dikoleksi dari tanah di sekitar perakaran tanaman ubi jalar yang telah dipanen.

\section{Aplikasi Steinernema spp.}

Setiap perlakuan menggunakan 10 ekor larva Lepidiota stigma instar 3, masing-masing larva disimpan secara terpisah pada wadah cup plastik, diameter bagian bawah wadah $2 \mathrm{~cm}$, tinggi $4 \mathrm{~cm}$, luas bagian bawah wadah $\pi \mathrm{r}^{2}=12,56 \mathrm{~cm}^{2}$. Wadah cup plastik diisi dengan 2 lapis kertas saring dan ubi jalar yang telah dipotong bebentuk kubus berukuran 1 $\mathrm{cm}^{3}$ sebagai makanan larva L. stigma. Selanjutnya larva L. stigma diinokulasi dengan Steinernema spp. sesuai dengan perlakuan dengan cara diteteskan pada larva dan kertas saring. Larva L. stigma yang telah diinokulasi dengan Steinernema spp. diinkubasi pada temperatur ruangan $\left(25^{\circ} \mathrm{C}\right)$ selama 72 jam. 


\section{Teknik Pengumpulan Data}

Pengamatan mortalitas larva Lepidiota stigma dilakukan pada 24 dan 48 jam setelah aplikasi (JSA) Steinernema spp. Pengamatan dilakukan terhadap jumlah larva L. stigma yang mati, dan mortalitas larva dihitung dengan rumus:

$$
\text { Mortalitas }=\frac{\mathrm{a}}{\mathrm{b}} \times 100 \%
$$

Keterangan :

$\mathrm{a}=$ Jumlah larva yang mati

$\mathrm{b}=$ Jumlah larva awal

Pengamatan perubahan warna larva L. stigma dilakukan pada 24 dan 48 JSA. Pengamatan dilakukan dengan melihat perubahan warna larva sampai larva tersebut mati. Hal ini sesuai dengan Zahro'in (2010) yang menyatakan bahwa gejala serangan pada inang yang mati oleh serangan Steinernema spp. dapat dikenali dengan adanya perubahan warna menjadi hitam kecoklatan atau caramel, karena pigmen yang dihasilkan pada serangga inang, Larva yang mati, kemudian dibedah dengan menggunakan mikroskop untuk membuktikan bahwa larva tersebut mati karena terinfeksi oleh Steinernema spp.

\section{Analisis Data}

Data dianalisis dengan analisis varians, dan untuk mengetahui perbedaan pengaruh di antara ratarata perlakuan dilakukan uji lanjut dengan Uji Jarak Berganda Duncan pada taraf nyata $5 \%$.

\section{HASIL DAN PEMBAHASAN}

\section{Mortalitas Larva Lepidiota stigma}

Aplikasi Steinernema spp. berpengaruh dalam meningkatkan mortalitas larva Lepidiota stigma dibandingkan dengan kontrol (tanpa Steinernema spp.) pada 24 dan 48 jam setelah aplikasi.

Tabel 1. Rata-rata mortalitas larva Lepidiota stigma pada aplikasi Steinernema spp.

\begin{tabular}{lll}
\hline \multirow{2}{*}{ Perlakuan } & \multicolumn{2}{l}{ Mortalitas Lepidiota stigma (\%) } \\
\cline { 2 - 3 } & 24 JSA & $48 \mathrm{JSA}$ \\
\hline A. Konsentrasi Steinernema spp. 0 JI/ml & $0,00 \mathrm{e}$ & $8,00 \mathrm{~d}$ \\
B. Konsentrasi Steinernema spp. $50 \mathrm{JI} / \mathrm{ml}$ & $8,00 \mathrm{~d}$ & $48,00 \mathrm{~b}$ \\
C. Konsentrasi Steinernema spp. $100 \mathrm{JI} / \mathrm{ml}$ & $20,00 \mathrm{c}$ & $40,00 \mathrm{c}$ \\
D. Konsentrasi Steinernema spp. $150 \mathrm{JI} / \mathrm{ml}$ & $28,00 \mathrm{~b}$ & $68,00 \mathrm{~b}$ \\
E. Konsentrasi Steinernema spp. $200 \mathrm{JI} / \mathrm{ml}$ & $44,00 \mathrm{~b}$ & $56,00 \mathrm{~b}$ \\
F. Karbofuran dosis $0,02 \mathrm{~g} / 12,56 \mathrm{~cm}^{2}$ & $92,00 \mathrm{a}$ & $92,00 \mathrm{a}$ \\
\hline
\end{tabular}

Keterangan : Angka yang diikuti dengan huruf yang sama pada kolom yang sama menunjukkan tidak berbeda nyata menurut uji jarak berganda Duncan pada taraf nyata 5\%. JSA = Jam Setelah Aplikasi

Pada pengamatan 24 JSA, aplikasi Steinernema spp. pada konsentrasi $50 \mathrm{JI} / \mathrm{ml}, 100$ $\mathrm{JI} / \mathrm{ml}, 150 \mathrm{JI} / \mathrm{ml}$ dan $200 \mathrm{JI} / \mathrm{ml}$ dapat menyebabkan mortalitas larva L. stigma sebesar $8-44 \%$ yang berbeda nyata dengan mortalitas pada kontrol (tanpa Steinernema spp.). Aplikasi Steinernema spp. 200 $\mathrm{JI} / \mathrm{ml}$ mengakibatkan mortalitas larva L. stigma $44 \%$. Aplikasi Karbofuran 0,02 g menyebabkan mortalitas larva L. stigma tertinggi (92\%) dibandingkan dengan mortalitas pada perlakuan lainnya.

Pada pengamatan 48 JSA, aplikasi Steinernema spp. menyebabkan peningkatan mortalitas larva L. stigma. Mortalitas larva L. stigma tertinggi $(68 \%)$ terdapat pada aplikasi Steinernema spp. $150 \mathrm{JI} / \mathrm{ml}$ yang tidak berbeda nyata dengan mortalitas larva L. sigma pada aplikasi Steinernema spp. $50 \mathrm{JI} / \mathrm{ml}$ dan $200 \mathrm{JI} / \mathrm{ml}$, tetapi berbeda nyata dengan mortalitas larva pada aplikasi Steinernema spp. $100 \mathrm{JI} / \mathrm{ml}$ dan kontrol.
Steinernema spp. pada konsentrasi 50, 100, 150 dan $200 \mathrm{JI} / \mathrm{ml}$ mampu membunuh larva L. stigma pada 24 dan 48 JSA. Aplikasi Steinernma spp. isolat Lembang pada konsentrasi $150 \mathrm{JI} / \mathrm{ml}$ mengakibatkan mortalitas larva L. stigma tertinggi $(68 \%)$ pada 48 JSA.

Terjadinya peningkatan mortalitas larva pada pengamatan 48 JSA menunjukkan bahwa nematoda Steinernema spp. memiliki kemampuan membunuh serangga dalam waktu yang singkat. Hal ini sesuai dengan pendapat Dowds \& Peters (2002) bahwa juvenil infektif (JI) Steinernema spp. mempenetrasi rongga tubuh serangga dan melepaskan bakteri simbiotik (Xenorhabdus spp.) yang berkembang biak dan menghasilkan metabolit yang mematikan serangga dan bertindak sebagai sumber makanan untuk nematoda. Hal ini karena setelah nematoda melakukan penetrasi ke dalam tubuh larva inang, sistem pencernaan nematoda yang semula tertutup 
mulai aktif membuka dan mengeluarkan bakteri simbion ke dalam hemolimfa dan mengakibatkan kematian pada serangga akibat toksin intraseluler dan ekstraseluler yang dihasilkan oleh bakteri simbion dalam waktu 24-48 jam (Kaya \& Gaugler 1993). Nematoda entomopatogen mampu menyebabkan mortalitas pada inangnya dalam waktu 24-48 jam karena dibantu oleh bakteri simbion masing-masing, yaitu bakteri Xenorhabdus sp. pada Steinernema sp. dan Photorhabdus sp. pada Heterorhabditis sp. (Dubey et al., 2013).

Toksin yang dihasilkan adalah eksotoksin seperti protease, lipase, lesitinase, dan endotoksin lipopolisakarida (komponen dalam dinding sel bakteri gram negatif), sehingga menyebabkan serangga inang mati septisemia (Dowds, 1998). Selain itu kecepatan membunuh dari nematoda entomopatogen terhadap inang merupakan refleksi dari daya bunuh bakteri simbion yang dibawa oleh nematode entomopatogen di dalam intestinumnya, terutama jumlah bakteri simbion yang dilepas ke dalam hemolimfa inang untuk membunuhnya secara efektif (Sicard et al. 2006).

Hasil pembedahan larva Lepidiota stigma yang mati dengan menggunakan mikroskop, ternyata ditemukan juvenile infektif Steinernema spp. yang masih hidup. Hal ini membuktikan bahwa larva L. stigma mati karena terinfeksi oleh Steinernema spp.

Gejala larva Lepidiota stigma yang terinfeksi oleh nematoda menujukkan perubahan warna tubuh dari warna putih menjadi coklat kehitamaan, dan dari dalam tubuhnya mengelurkan cairan. Hal ini sesuai dengan gejala yang dilaporkan oleh Simoes \& Rosa (1996), bahwa terjadinya perubahan warna dan tubuh menjadi lunak disebabkan oleh bakteri simbion Xenorhabdus spp. yang mengeluarkan toksin (eksotoksin) sehingga menyebabkan paralisis dan kematian serangga. Steinernema spp. dan Larva Lepidiota stigma yang mati (Gambar 1 dan Gambar 2).

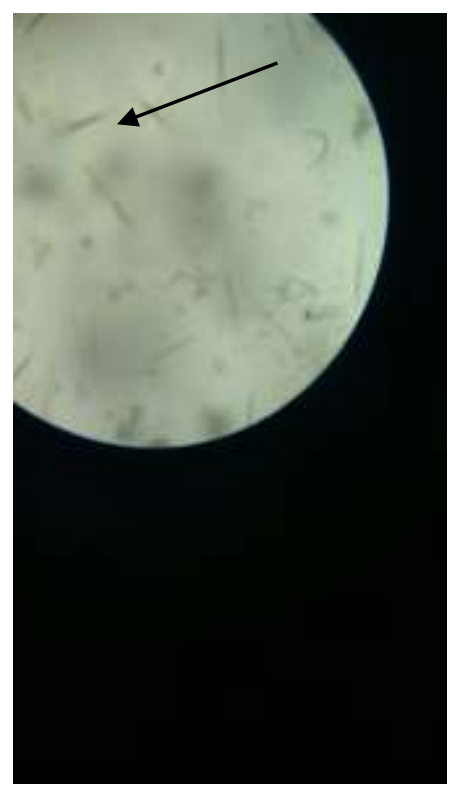

Gambar 1. Steinernema spp.

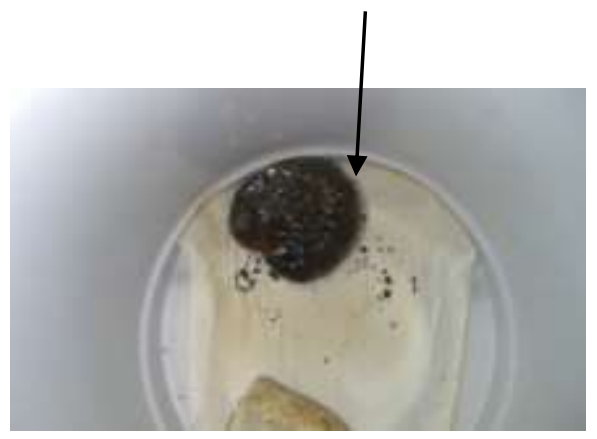

Gambar 2. Lepidiota stigma yang mati

\section{KESIMPULAN}

Berdasarkan hasil dan pembahasan dapat disimpulkan sebagai berikut:

1. Sterinernema spp. berpengaruh efektif terhadap mortalitas larva Lepidiota stigma pada pengamatan 24 dan 48 jam setelah aplikasi.

2. Steinernema spp. pada konsentrasi $150 \mathrm{JI} / \mathrm{ml}$ efektif menyebabkan mortalitas larva Lepidiota stigma $(68 \%)$ pada 48 jam setelah aplikasi.

\section{UCAPAN TERIMA KASIH}

Penelitian ini terlaksana berkat kerjasama dengan Dekan Fakultas Pertanian Universitas Padjadjaran melalui skema Penelitian Mandiri Tahun 2019. Penulis mengucapkan terima kasih kepada
Dekan Fakultas Pertanian Universitas Padjadjaran, Kepala Pusat Studi Pengembangan Produk dan Kemitraan, dan Pija Saefullah, SP. atas bantuan dan kerjasamanya dalam pelaksanaan penelitian ini.

\section{DAFTAR PUSTAKA}

Abdolmaleki, A., Z.T. Maafi , H.R. Dastjerdi, B. Naseri, \& A. Ghasemi. 2016. Isolation and identification of entomopathogenic nematodes and their symbiotic bacteria from Kurdistan Province in Iran. Crop Protection, 5 (2), 259-271. doi: 10.1016/j.jip.2008.01.006.

Andaló, V., G.F. Moreira, \& A.M. Junior. 2017. Hostseeking behavior of the Heterorhabditis 
amazonensis nematode in response to stimulant sources. Pesquisa Agropecuária Tropical, 47 (3), 265-272. doi: 10.1590/1983-40632016v4745395

Arthers, S., K.M. Heinz, J.R. Prasifka. 2004. An analysis of using entomopathogenic nematode against abovegroundpests. Bull Entomol Res. 94:297-306.

Chandel RS, M. Pathania, K.S. Verma, B. Bhatacharyya, S. Vashisth \& V. Kumar. 2015. The ecology and control of potato white grubs of India. Potato Res. 58: 147164.

Dowds, BCA. 1998. Bacterial Virulence Mechanisms Pp. 9-16 in Simoes N., M.N. Boe, R.U. Ehlrs (Eds.) Entomopathogenic Nematodes. Patogenicity of Entomopathogenic Nematodes Versus Insect Defence Mechanism: Impact on Selection of Virulent Strain Italy. European Cooperation in the Field of Scientific and Technical Research. COST 819.

Dowds, B.C.A. \& A. Peters. 2002. Virulence mechanisms. Pp.79-98 in R. Gaugler (ed) Entomopathogenic Nematology. CABI, New York, USA.

Dubey, J., B.N. Tiwary \& S. Ganguly. 2013. Biological control of insect pests using entomopathogenic nematodes. In: Maramorosch, K. \& Hirumi, H. (eds.) Practical Tissue Culture Applications. Rio de Janeiro, Elsevier Inc., pp. 387-398.

Kapranas, A., A.M.D. Maher \& C.T. Griffin. 2018 The influence of organic matter content and media compaction on the dispersal of entomopathogenic nematodes with different foraging strategies. Parasitology, 144, 19561963. doi:10.1017/S003118- 2017001317.

Kaya, H.K. \& R. Gaugler. 1993. Entomopathogenic nematodes. Ann. Rev. Entomol.38: 181206.

Lee, J.H., A.R. Dillman \& E.A. Hallem. 2016. Temperature-dependent changes in the Host- seeking behaviors of parasitic nematodes. BMC Biology, 14 (36), 1-17. doi:10.1186/s12915-016-0259-0.

Maneesakorn, P., R. An, , P.S. Grewal. \& A. Chandrapatya, (2010) Virulence of four new strains of entomopathogenic nematodes from Thailand against second instar larva of the Japanese beetle, Popillia japonica (Coleoptera: Scarabaeidae). Thai Journal of Agricultural Science, 43 (2), 61-66.

Pathania M. 2014. Studies on phytophagous white grubs of Himachal Pradesh. Ph.D Thesis, Department of Entomology, CSK Himachal Pradesh Krishi Vishvavidyalya, Palampur, India; p. 258.

Saragih, D.M. 2009. Serangan uret dan cara pengendaliannya pada tanaman Eucalyptus hybrid di Hutan Tanaman PT. Toba Pulp Lestari Sektor Aek Na Uli Sumatera Utara. Departemen Silvikultur.

Sicard, M., J. Hinsinger, N. Le Brun, S. Pages, N. Boemare \& C. Moulia. 2006. Interspecific competition between entomopathogenic nematodes (Steinernema) is modified by their bacterial symbionts (Xenorhabdus). BMC Evolutionary Biology, 6, 1956- 1963. doi:10.1186/1471-2148-6-68.

Simoes, N., \& J.S. Rosa. 1996. Pathogenicity and Host Specifity of Entomopathogenic Nematodes. Biocontrol Science and Technology. (6): 403-411.

Upadhyay, D., S. Mandjiny, R. Bullard-dillard, M. Storms, M. Menefee \& L.D. Holmes. 2015 Lab-scale in vitro mass production of the entomopathogenic nematode Heterorhabditis bacteriophora using liquid culture fermentation technology. American Journal of Bioscience and Bioengineering, 3 (6),203207. doi:10.11648/j.bio.20150306.19.

Zahro'in, E., 2010. Nematoda Entomopatogen APH Mematikan tetapi Ramah Lingkungan. http://ditjenbun.deptan.go.id.

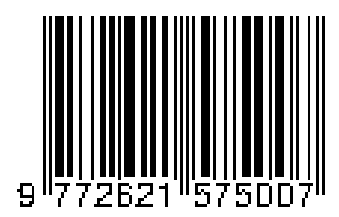

